This is the pre-print of then article published in the journal Knowledge Management Research and Practice. The final authenticated version is available online at:

Berbegal-Mirabent, J.; Gil-Doménech, D.; Ribeiro-Soriano, D. (2020). Fostering universityindustry collaborations through university teaching. Knowledge Management Research \& Practice, 18(3): 263-275. https://doi.org/10.1080/14778238.2019.1638738

\title{
Fostering university-industry collaborations through university teaching
}

The importance of university-industry links and their impact on innovation processes have been widely acknowledged. However, previous studies have mainly examined university-industry knowledge transfer activities from the perspective of the research and third stream missions. This paper goes a step further, analysing such processes from the perspective of the university's teaching mission. More specifically, it explores how educational crowdsourcing platforms help bring universities and industry together to develop joint activities in undergraduate and graduate programmes. To do so, this paper presents a qualitative study based on secondary data from the websites of a range of platforms. This study enabled us to identify three categories of educational crowdsourcing platforms depending on their focus (education, crowdsourcing, or networking). The analysis shows that, although these platforms have some shortcomings, they provide benefits to all stakeholders by facilitating experiential learning, promoting skills acquisition and encouraging the development of new ideas to meet industry needs.

Keywords: teaching; online platform; crowdsourcing; university-industry; knowledge transfer

\section{Introduction}

Universities are key components of regional innovation systems. As employers, they create job opportunities; as suppliers, they provide a highly skilled workforce and technological know-how in the form of human capital, products, services and even new ventures; and as consumers, they require resources and services to effectively perform 
their core activities (Vilalta et al., 2010). Unsurprisingly, given universities' strength at generating economic activity (Kelly et al., 2010), the number of theoretical discussions debating the way universities operate and their role in innovation systems has multiplied over the past three decades (Abbas, Avdic, Xiaobao, Hasan, \& Ming, 2018; Franco \& Pinho, 2018). The result is an extensive body of literature that covers the theories of 'Mode 2' (Gibbons et al., 1994), the 'Triple Helix' model (Etzkowitz \& Leydesdorff, 1997) and the engaged university (Chatterton \& Goddard, 2000; Holland, 2001), amongst others. These theories link the traditional categories of the innovation economy to evolutionary economics (Ebbers, 2014; Somsuk \& Laosirihongthong, 2014; Tacer, Ruzzier, \& Nagy, 2018), describing the linkages between the three institutional actors (public, private and academic) and capturing the reciprocal relationships derived from their interactions.

These theoretical efforts have been accompanied by the deployment of a wide array of innovation and technology transfer policies. These policies aim at providing the right conditions to enhance university-industry (U-I) partnerships that lead to the effective exploitation of the knowledge housed in universities (Munari et al., 2016). In Europe, the European Commission has also developed explicit support initiatives and programmes to encourage the establishment of long-term partnerships between higher education and the business world. One example is the University-Business Forum, an annual event held in Brussels since 2008 that brings together higher education institutions, companies, business associations, public authorities and policymakers to network and exchange ideas and best practices.

Although U-I links and their impact on innovation processes have been a longstanding target of analysis (Mascarenhas et al., 2018), previous studies have mainly focused on activities that provide economic value to academic research (Perkmann et 
al., 2013). Patents, licenses, spinoffs and R\&D contracts are the most common metrics used to evaluate how actively a university collaborates with industry (Chen et al., 2016). However, these mechanisms represent only a part of what U-I collaborations actually mean. To make a difference, university research must be meaningful for industry (Ribeiro-Soriano \& Berbegal-Mirabent, 2017). The expansion of the knowledge-based society has forced universities to become more closely involved in community life (Mirjana, Ana, \& Marjana, 2018; Rusu \& Roman, 2018). This shift means broadening the traditional understanding of U-I knowledge transfer. Following Davey et al. (2014) we define U-I knowledge transfer processes as any kind of formal or informal cooperative interaction between universities and businesses for mutual benefit.

Prior studies have mainly examined U-I knowledge transfer from the perspective of the research and third stream missions (Wang et al., 2016). In this paper, however, we go further and respond to recent calls for the rigorous study of this process from the perspective of the university’s teaching mission (Galán-Muros \& Plewa, 2016; Kunttu, 2017). Education is the oldest way that academia contributes to economic growth. Students act as important channels through which knowledge is transmitted to industry. However, we argue that knowledge flows also occur during education and not only after graduation. Consequently, the focus of this paper is on initiatives that pursue a closer cooperation between higher education institutions and businesses through the development of new teaching and learning approaches that meet the needs of students by endowing them with the skills required by the market - and companies - by providing solutions to their problems. Specifically, we investigate the underexamined role of educational crowdsourcing platforms (Soendergaard et al., 2015), which link universities and industry to develop joint activities in undergraduate or graduate programmes. 
Such platforms or online environments, whether designed by a university or an independent company, are increasingly attracting attention from academics and companies alike. For students, these platforms provide the opportunity to fully immerse themselves in real projects and gain a thorough understanding of how companies work. Participating in such activities has been shown to increase students' employability, enrich their learning process and better prepare them for the world of work (Ishengoma \& Vaaland, 2016; Helyer \& Lee, 2014). For businesses, these platforms provide access to new inflows of knowledge and shorten the time lag between making and applying discoveries. By partnering with universities, companies access a skilled labour force, consisting of not only students but also faculty and technical staff, which is expected to bring a fresh approach to their problems. At the same time, this strategy allows businesses to attract new talent and investigate or start projects in areas that, because of a lack of time or resources, would otherwise remain underexplored. This strategy is particularly appealing to start-ups, SMEs and family businesses. Typically, their size and resources means that such firms struggle to survive in an increasingly globalised world (Van de Vrande et al., 2009). Nonetheless, university-business alliances are not limited to SMEs, and, aware of the advantages they might provide, large corporations regularly collaborate with universities.

The remainder of the article is structured in separate sections. We first provide a detailed literature review of different mechanisms of U-I processes linked to the university's teaching mission. Second, using a sample of U-I knowledge transfer educational crowdsourcing platforms, we qualitatively investigate the way these platforms work, paying special attention to how the different challenges posed by companies are introduced in the classroom. Based on this analysis, we make a series of 
recommendations that we expect to help institutionalise knowledge transfer activities between industry and universities.

\section{Literature review}

\subsection{Fostering $U$-I partnerships through teaching}

Universities are valuable sources of new knowledge. Growing pressure in the demographic, economic, technological, social and political spheres makes universities active vehicles for economic progress. Today's globalised and competitive business environment requires companies to rapidly innovate to meet customers' demands (Ivascu et al., 2016). Yet companies lack some of the skills they need to develop such products in house. The best way of meeting these requirements is through collaboration with external partners. Successful U-I partnerships are therefore attractive. However, whereas universities are generally oriented towards generating new, fundamental knowledge and developing a scientific reputation, industry usually focuses on profit and practice. Given these differences in the primary objectives and orientation of universities and industry, certain barriers prevent U-I partnerships from fully developing (Albats et al., 2016). Nevertheless, impetus for a deeper relationship does exist (Striukova and Rayna, 2015).

Like della Volpe (2018), we argue that to come up with meaningful U-I partnerships, the university model must be redesigned. Furthermore, we argue that this transformation should stem from the teaching mission. Letting companies participate in curriculum design and delivery not only involves them in universities' first mission (i.e. teaching) and enriches lectures through real experiences but also aligns the curriculum with industry's needs (Plewa et al., 2015). This kind of collaboration benefits all parties. Companies access new talent, leading technologies and product development 
capabilities, whilst universities obtain new ideas and resources for teaching (and probably, by extension, research) and orient students' skills and abilities towards industry requirements.

The theoretical underpinnings for this approach are found in open innovation and crowdsourcing. According to Chesbrough (2006), open innovation advocates the use of inflows and outflows of knowledge to accelerate firms' innovation processes and capitalise on markets. In this context, different agents (Wu et al., 2013; Felin \& Zenger, 2014), whether internal or external (Padilla-Meléndez et al., 2012), are involved in the innovation process. Aligned with the principles of open innovation, crowdsourcing allows organisations to gather ideas or content by soliciting contributions from a large group of people, especially an online community, rather than traditional employees or suppliers.

As knowledge intensive organisations (De la Torre et al., 2016), universities can play a valuable role as external suppliers (Ferri et al., 2018). A closer look at how universities function reveals that teaching activities, if properly designed, can act as powerful mechanisms for new knowledge generation and, consequently, can contribute to innovation in the wider economy. A European Commission (2017) report highlights that, in recent years, the university's traditional approaches to teaching have shifted towards a more pro-active, inquiry-based, co-creative model. Universities and industry can create a realistic and effective learning environment by challenging students to work on real business problems, research trials, or unresolved tasks that corporations have yet to complete (della Volpe, 2018; Galán-Muros et al., 2016). Such programmes typically take the form of structured projects, unlike the simulated academic environment, and encourage students to find a solution before a certain deadline. By working side by side with the company and using a mix of design thinking, agile co- 
creation, the scenario approach and demo-building, students explore the future, generating and refining their ideas.

There is evidence (see section 4 for some examples) that this approach is effective at reinforcing the communication and knowledge transfer between employers and those who educate them. More specifically, from a company's perspective, interest in taking part in such a U-I agreement refers not only to the solution itself but also to the chance to learn new ways of thinking from highly educated millennials, discover young talent and identify potential employees. In turn, academics can benefit from real-world cases, opening the door to modern learning experiences whilst adjusting the curriculum to the needs of the marketplace (Baaken et al., 2015). Lastly, students become more engaged in the learning process than they do with traditional classroom teaching because they have to reflect on developing and using their ideas to carry out projects effectively. They apply and retain new knowledge, become more independent and responsible and improve their performance not only during the activity but also afterwards (Michael, 2006; Bell \& Kozlowski, 2008). Thus, such programmes offer a great opportunity for students to enrich their CVs with a unique skillset. Furthermore, students have the chance to make contacts in industry and thus identify future employers, get career advice or even start their own businesses if they are inspired by a challenge they have worked on.

The next section elaborates on educational crowdsourcing platforms. These represent a new trend that is disrupting the educational landscape by connecting and facilitating knowledge flows between universities and industry.

\subsection{Educational crowdsourcing platforms}

Technological advances in the educational setting have provided new opportunities for universities. First, they afford access to knowledge transfer processes. Second, they 
encourage greater interaction between students and other agents, enabling new ways of teaching and learning. Moreover, thanks to open source initiatives championed by individuals, organisations can access knowledge generated outside the university. Also, the new types of innovative processes enabled by technological advances confer speed and effectiveness on future improvements (Kulakli \& Mahony, 2014).

In this context, technology has characteristics that can undoubtedly aid cocreation, mainly in relation to collaborative learning and knowledge production. Collaborative learning has a close connection with social learning. It focuses on students and embraces innovation, whereas collaborative knowledge creation requires universities to change to more open and flexible structures (Tapscott \& Williams, 2010). All these elements are present in the current technological context, which has transformed sharing structures, increased information flows, expanded the number of teaching and learning activities, improved access to information and ultimately promoted the creation of new content and fostered the development of skills such as the ability to select information, collaborate or work in a team (Kulakli \& Mahony, 2014).

To promote U-I co-creation, supportive spaces with relevant services are necessary (Huhtelin \& Nenonen, 2015). Educational crowdsourcing platforms can provide just such supportive spaces. Such platforms transfer the crowdsourcing model to the academic environment by offering a virtual space where companies can connect with students to solve real business challenges. According to Albats et al. (2016), these platforms facilitate multidisciplinary co-creation projects by placing students at the centre of the educational process.

Although specific goals might differ slightly from platform to platform, projects typically have three stages. First, private or public companies register with the platform to find new ideas for their businesses. They upload their projects (challenges) and 
students (or the university) decide which one they would like to work on. Next, the students, university and company agree on the details of the deliverables and assessment procedure. Second, once a successful match has been made, the ideation and implementation stage starts. Regular meetings, either face to face or virtually, between students and the company are scheduled to provide regular feedback to help students shape their proposals according to the company's requirements. In addition to meetings between the students and the company, the course instructor also offers advice. Lastly, both the company and the instructor participate in the evaluation stage. Whereas the company mainly assesses whether the solution is feasible and aligned with its vision, the course instructor will also evaluate students' commitment to the project and progress throughout the project. In some instances, incentives such as rewards or prizes are used as additional extrinsic motivators.

The following sections provide detailed analysis of several relevant educational crowdsourcing platforms. This analysis enables the characterisation of these platforms.

\section{Case study}

\subsection{Sample}

Educational crowdsourcing platforms were selected based on their importance. There is no official listing, so we chose the platforms that had received considerable attention either in the academic literature or in press releases and newspaper articles. The sample contains platforms that run different business models. EduSourced, CapSource, Demola, Nimble Bee and Agorize are private initiatives. These private companies act as intermediaries that bring companies and universities together. In contrast, $U C$-CROWD and Semester of Code are the result of publicly funded European projects. Here, a consortium of partners (including private, public and research organisations) typically 
led by a university handles the crowdsourcing projects. Lastly, we included Sí Somos Innovación and e-Start, two platforms that are run by a foundation.

\subsection{Method}

This study is qualitative and exploratory. It aims at analysing different platforms to investigate how they function and which elements characterise them. Specifically, the characteristics under analysis relate to the following:

- Purpose: Objective, value proposition and main features.

- Basic information: Founder, initiative (private or public), foundation date and web traffic.

- Performance and functionality: Eligibility to join (students from partner universities, graduates/undergraduates or anyone), matching (the user who performs the matching process of linking the project to students: students, companies, university professors or the platform), team composition, scope (projects, internships or events), methodology and ownership of the intellectual property (IP).

- Revenues: Sources of funding (who pays the fees).

The data extraction was conducted by checking the platforms' websites and gathering all available data on objectives, audience, functionality and performance. Information on web traffic was obtained from www.semrush.com. The analysis of the aforementioned characteristics was expected to provide useful insights that would enable us to understand the nature of these platforms and consequently propose recommendations to help institutionalise U-I knowledge transfer activities. 


\section{Results}

The selected educational crowdsourcing platforms aim at reinforcing links between universities and industry. To do so, they provide universities with different learning experiences as part of their programmes, whilst companies benefit from these experiences by obtaining solutions to their problems or challenges, identifying potential, raising their visibility, getting closer to young talent and/or receiving information about critical innovations and trends.

Most of the analysed crowdsourcing platforms are private initiatives created by independent companies. For example, EduSourced bases students' learning on the solution of real problems. A key advantage and differentiator of this platform is that it supports every step of the project management. Specifically, it tracks the project progress and deliverables, provides information about all project and team collaborations and records all client activities linked to current and past projects. CapSource and Demola are also private initiatives that use real projects to introduce students to experiential learning. The differentiating feature of CapSource is that it is responsible for matching teams to projects, whereas Demola is characterised by multidisciplinary teams formed of students from different disciplines and industry experts. Another platform run by an independent company is Nimble Bee, which provides solutions to product or engineering innovation challenges through competition. The last private platform, Agorize, differentiates itself by organising large-scale real-life events to solve business challenges. Each challenge has an average of 150 teams. This platform not only focuses on student challenges such as the one considered in this study but also offers start-up challenges and online hackathons.

The other platforms were founded by non-profit organisations or by universities with the support of European projects. Two platforms were formed by non-profit 
organisations. Sí Somos Innovación, which was founded by a public foundation (University of Oviedo Foundation), promotes the use of projects to generate an ecosystem of industry, students and higher education institutions in Gijón (Spain). The other platform, $e$-Start, which was founded by a non-profit private foundation (Fundación Universidad-Empresa), offers online internships to university students. Two platforms were created by universities and are supported by European projects. The first, $U C$-CROWD, supported by the Lifelong Learning Programme of the European Commission, seeks to create a platform (Challenge Academy) to promote international networking between companies and higher education institutions in the field of energy. The second, Semester of Code, which is backed by the VALS European project, is based on experiential learning through projects. It works with universities and free and open source software (FOSS) projects to bring real-world experiences from the software industry to students.

Table 1 (for basic data and financial gains) and Table 2 (for performance and functionality) summarise the main characteristics of the platforms to enable comparison. After carefully examining these characteristics, three main types of platforms can be defined based on their scope.

Platforms that track the full learning experience. Platforms in this category bring businesses and university students together to overcome a challenge (project) whilst emphasising how students progress throughout the project and recording all intermediate outcomes of the interactions between students, the business and the teacher. One example is EduSourced, a platform that covers the entire process from project proposal to evaluation. This focus implies that the platform is designed to assist professors' management of the project and enable access to past projects by archiving other experiences. Specifically, through this platform, professors can create and 
supervise projects, form teams of students, clients and scholars, access a repository of all project-related information (e.g. proposals, active projects, outcomes and archives, student communications, feedback from clients, attachments and reports) and monitor project status and success.

Platforms with a predominant focus on crowdsourcing. These platforms emphasise the 'open' approach of gathering ideas using different strategies to make this 'call' for ideas more appealing. Nimble Bee belongs to this category. In this case, the UI interaction takes the form of a competition. The outputs are validated by the company or even by end users, whilst the teacher adopts a secondary role. The use of games and this user-centred approach has other noteworthy benefits. Specifically, the literature shows that the use of games with educational purposes helps students' assimilation of ideas and concepts (Wilson et al., 2009) and improves students' confidence (Ku et al., 2014). Therefore, combining the search for a solution to companies' challenges with competitions can lead to better outcomes. However, focusing only on ideas and designs rather than using projects to respond to such challenges could impoverish the learning process. Studies have shown that the use of projects for educational purposes enhances students' knowledge acquisition because it helps students understand the whole process (Masek \& Yamin, 2012) and develop teamwork and communication skills (MachoStadler \& Elejalde-García, 2013). In short, platforms in this category are characterised by creating opportunities to physically bring together companies and universities to engage in specific events (e.g. a business competition challenge).

Platforms oriented towards networking. These platforms aim at mapping a network between all stakeholders to facilitate the search for capabilities, skills and talent. Platforms in this category might have a strong geographical scope, connecting stakeholders in a specific region (e.g. Sí Somos Innovación operates in Gijón, Spain). 
Alternatively, they might adopt a field-specific approach to create a powerful innovation cluster in a specific knowledge area.

The above categories are not mutually exclusively but rather complement each other. For instance, $e$-Start falls into all three categories. On $e$-Start, students are assigned to internships in the form of pre-consulting projects. These projects can be configured as curricular internships (crowdsourcing) that are closely tracked by stakeholders on the platform (a common feature of platforms in the first category). Although the geographical scope is not well defined, most companies posting projects are located in neighbouring regions in Spain. Table 3 reports the main advantages of each type for the four main stakeholders (students, academics, universities and companies).

\section{Discussion}

In recent decades, there has been growing interest in enhancing the engagement of universities with society and an increasing expectation that they should be more closely involved in community life (European Commission, 2010). As a response, universities have begun to redefine their role by introducing new ways of engaging more efficiently with society's demands, better allocating resources and becoming more attractive for professors, researchers, students and companies (Hazelkorn, 2005; Van Vught, 2009).

One way to do so is to establish university-industry partnerships. Aiming at capitalising on the innovation potential of both universities and businesses, such collaborations are envisaged as an effective way of promoting the exchange of ideas and expertise. The academic literature highlights a host of benefits arising from such alliances (Davey et al., 2011). Yet collaboration through teaching is still limited and remains poorly documented in the academic literature (Ankrah \& Omar, 2015). Based 
on the existing evidence and further analysis of the specific case of educational crowdsourcing platforms, several policy implications may be formulated.

First, to facilitate the partnership, the platform would benefit from a comprehensive service offer: a simple but user-friendly interface able to track all the project stages from project upload to project completion and evaluation. This is the model followed by EduSourced, which, through a comprehensive service offer, allows stakeholders to follow up on the entire process and track all project activities, outcomes and reporting. This model requires an integrated system, so its cost might be high. However, the advantages for both companies and universities are considerable in that this model helps with the task of supervision.

Second, successfully completing business projects makes the learning process more meaningful. However, the analysis shows that projects are not compulsory for students in all cases. Consistent with Huhtelin and Nenonen (2015), we argue that to ensure the active commitment of all stakeholders, solutions for these projects should somehow be inserted into the curriculum and should be co-designed by academics and practitioners. Regarding making the project part of the curriculum, receiving explicit extrinsic incentives (e.g. grading) for taking an active role in the project might increase students' commitment not only with the specific work but also with their studies. However, the scope of the project must be time bound and manageable, avoiding generic proposals that might overwhelm students because of uncertainty and an excessive array of possibilities. In terms of curriculum co-design, despite numerous advantages of such practices (Davey et al., 2011; Siegel et al., 2004), scholars have questioned whether the influence of businesses might lead to bad practices (Plewa et al., 2015). The main concerns refer to the manipulation of scientific knowledge in favour of 
business interests (Krimsky, 2003) and the involvement of academics at the expense of scientific objectivity (Barnett, 2002).

Third, there is a widespread belief that despite their expertise, universities do not contribute as much as they could to innovation in the wider economy (European Commission, 2017). To design and implement an effective educational model that is relevant to society and prepares graduates for a dynamic and evolving labour market, a forum for structural cooperation and dialogue between universities, businesses and the public sector is required. We argue that challenging students with business projects takes steps in this direction and can help universities address the following new educational needs: (i) providing horizontal and specific skills in response to labour market demands (Boulton \& Lucas, 2011; Čepić \& Krstović, 2011); (ii) supporting graduates to help them access the labour market (Washer, 2007); and (iii) matching training programmes to business/social needs. As highlighted in the Eurydice report (2014), nine EU countries regularly use labour market information to plan their higher education programmes, yet this trend is still not generalised.

Fourth, in addition to all the benefits described in the previous sections, educational crowdsourcing platforms also boost international experience, particularly platforms that bring students from universities in different countries together to solve a problem for a company located elsewhere. This cross-country dimension is a powerful tool for attracting student participation. Working in an international environment has the potential to aid not only career development but also personal growth (Amendola \& Restaino, 2017). Although geographical proximity is sometimes desirable, location is no longer the main basis for selecting a partner given recent strides in information and communication technology. Educational crowdsourcing platforms are designed to 
operate in this setting. Because technology lies within students' reach, students can enjoy this international experience without the cost of travelling.

Fifth, universities focus on generating new, fundamental knowledge, whereas industry focuses on profits and practice. Given these differences in orientation (Albats et al., 2016), certain barriers might hinder the potential of educational crowdsourcing platforms. To overcome these obstacles, several aspects must be carefully addressed to design an enabling environment. A key issue refers to the ownership of the intellectual property resulting from the project. A model that is fair for all parties should be agreed upon before starting the project. Students should not feel that they are used as just another company resource but should instead feel like a valuable source of fresh ideas with market value. Another key aspect to control for is the rigidity of the agreement. Although all the terms of the partnership should be stipulated in the contract, some flexibility should be allowed because of the openness of the co-creation process and the high speed at which society's demands change (Huhtelin \& Nenonen, 2015). Acting thus would lead to trustful relationships and, consequently, enduring bonds between academia and industry.

Sixth, educational crowdsourcing platforms present a new pedagogical challenge for instructors. Changing the way learning and teaching are carried out requires not only committed teachers who are willing to invest time in designing alternative teaching material but also trained professionals who must learn how these platforms work and how this new approach to learning should be implemented within the students' learning processes. Unfortunately, to develop an academic career and consolidate a senior position within academia, research outputs are far more important (Berbegal-Mirabent, 2018) than the design and implementation of innovative teaching practices. This bias towards research output might prevent scholars from improving 
their teaching practices when, actually, both teaching and research should be encouraged equally.

Lastly, it is worth questioning who should take the lead role in promoting educational crowdsourcing platforms and who can make best use of them. The analysis reveals two distinct strategies that are typically followed for taking the lead role. In the first, a private intermediary between businesses and academia is responsible for the partnership, bringing together businesses and universities and acting as knowledge brokers. In the second, a different pattern is observed for consortia, in which a university takes the lead role. Both approaches are equally valid. The key issue is to ensure the sustainability of the platform over time. Regarding who can make best use of these platforms, the analysis indicates that projects are mainly proposed by businesses. However, these platforms can also be used by other sectors such as the public administration. This strategy would empower students to democratise community services and thus view themselves as important and valued contributors instead of passive recipients. Likewise, NGOs, associations and other such organisations might find these platforms useful for generating collective awareness of their projects. Using these online environments to gather ideas to solve collective problems might deliver a transformational change in student engagement whilst linking activism for sustainable development with formal education. Undoubtedly, there is still room for improvement to make the most of such platforms.

\section{Concluding remarks}

This paper contributes to the U-I research by focusing on U-I knowledge transfer collaborations from the teaching perspective. We analysed educational crowdsourcing platforms as a new way to promote this kind of collaboration and investigated the role of such platforms for the development of U-I joint activities in undergraduate or 
graduate programmes. Benefits arising from the integration of such platforms within the design and delivery of university curricula have been highlighted. Notably, these platforms lend meaning to the learning process, help build an educational model that is relevant to society and better prepare students for the labour market whilst promoting international experience.

Although we followed the scientific standards for gathering, classifying and interpreting the data, the study nonetheless has some limitations. These limitations provide opportunities for future research. In terms of the research objectives and data availability, this study is of a markedly descriptive and exploratory nature. Now that the fundamentals of this issue have been established, further studies should examine performance. Topics of interest might include examining users' perceptions (i.e. the perceptions of students, companies and universities); the impact that participating in such activities has on students' performance, students' skills development and students' access to the labour market; and the extent to which companies use students' solutions. Another limitation refers to the platforms that we analysed. All have received attention either in the academic literature or in the press, validating their relevance. However, other similar platforms might also be worthy of examination. Finally, future research might benefit from the incorporation of primary data from, for example, interviews with the owners or creators of the platforms or with users to provide additional relevant data not reported on the platforms' websites.

\section{References}

Abbas A, Avdic A, Xiaobao P, Hasan MM and Ming W (2018) University-government collaboration for the generation and commercialization of new knowledge for use in industry. Journal of Innovation \& Knowledge https://doi.org/10.1016/j.jik.2018.03.002. 
Albats E, Figenbaum I and Alexander AT (2016) Innovation intermediaries in university-industry collaboration: Analysis of online platforms. In XXVII ISPIM Innovation Conference - Blending Tomorrow's Innovation Vintage, Porto (Portugal), June19-22.

Amendola A and Restaino M (2017) An evaluation study on students' international mobility experience. Quality \& Quantity 51(2), 525-544.

Ankrah S and Omar AT (2015) Universities-industry collaboration: A systematic review. Scandinavian Journal of Management 31(3), 387-408.

Baaken T, Kiel B and Kliewe T (2015) Real world projects with companies supporting competence development in higher education. International Journal of Higher Education 4(3), 129-139.

Barnett M (2002) University-industry relationships in dentistry: Past, present, future. Journal of Dental Education 66(10), 1163-1168.

Bell BS and Kozlowski SW (2008) Active learning: effects of core training design elements on self-regulatory processes, learning, and adaptability. Journal of Applied Psychology 93(2), 296-316.

Berbegal-Mirabent, J. (2018). The influence of regulatory frameworks on research and knowledge transfer outputs: An efficiency analysis of Spanish public universities. Journal of Engineering and Technology Management 47, 68-80.

Boulton G and Lucas C (2011) What are universities for? Chinese Science Bulletin 56(23), 2506-2517.

Chatterton P and Goddard J (2000) The response of higher education institutions to regional needs. European Journal of Education 35, 475-496.

Chen A, Patton D and Kenney M (2016) University technology transfer in China: a literature review and taxonomy. Journal of Technology Transfer 41(5), 891929.

Chesbrough HW (2006) Open innovation: The new imperative for creating and profiting from technology. Harvard Business Press, Cambridge, MA.

Čepić R and Krstović J (2011) Through lifelong learning and learning organisations towards sustainable future. International Journal of Innovation and Learning 10(2), 195-213.

Davey T, Baaken T, Galán-Muros V and Meerman A (2011) Study on the cooperation between Higher Education Institutions and Public and Private Organisations in Europe. European Commission, DG Education and Culture, Brussels, Belgium. 
Davey T, Plewa C and Muros VG (2014) University-Business cooperation outcomes and impacts. A European Perspective. In T Kliewe and T Kesting (Eds.), Moderne Konzepte des organisationalen Marketing (pp. 161-176). Springer Gabler, Wiesbaden.

De la Torre R, Lusa A and Mateo M (2016) A MILP model for the long term academic staff size and composition planning in public universities. Omega $\mathbf{6 3}, 1-11$.

della Volpe M (2018) Entrepreneurial university and business education: Towards a network model. International Journal of Business and Management 13(3), 1327.

Ebbers JJ (2014) Networking behavior and contracting relationships among entrepreneurs in business incubators. Entrepreneurship Theory and Practice 38(5), 1-23.

Franco M and Pinho C (2018) A case study about cooperation between University Research Centres: Knowledge transfer perspective. Journal of Innovation \& Knowledge https://doi.org/10.1016/j.jik.2018.03.003.

Galán-Muros V and Plewa C (2016) What drives and inhibits university-business cooperation in Europe? A comprehensive assessment. $R \& D$ Management 46(2) 369-382.

Galand B, Frenay M and Raucent B (2012) Effectiveness of problem-based learning in engineering education: A comparative study on three levels of knowledge structure. International Journal of Engineering Education 28(4), 939-947.

Etzkowitz H and Leydesdorff L (1997) Introduction: Universities in the global knowledge economy. In H Etzkowitz and L Leydesdorff (Eds.), Universities and the global knowledge economy: A Triple Helix of university-industrygovernment relations (pp. 1-18). Pinter, London and Washington.

European Commission (2017) Communication from the Commission to the European Parliament, the Council, the European Economic and Social Committee and the Committee of the Regions. A renewed EU agenda for higher education, COM(2017) 247 final. European Commission, Brussels, Belgium.

European Commission/EACEA/Eurydice (2014) Modernisation of higher education in Europe: Access retention and employability 2014. Eurydice report. Publications Office of the European Union, Luxembourg. 
European Commission. (2010). Focus on higher education in Europe 2010: The impact of the Bologna Process. Education, Audiovisual and Culture Executive Agency publications, Brussels.

Felin T and Zenger TR (2014) Closed or open innovation? Problem solving and the governance choice, Research Policy 43(5), 914-925.

Ferri L, Ginesti G, Spanò R and Zampella A (2018) Exploring the entrepreneurial intention of female students in Italy. Journal of Open Innovation: Technology, Market, and Complexity 4(3), 27-37.

Galán-Muros V and Plewa C (2016) What drives and inhibits university-business cooperation in Europe? A comprehensive assessment. $R \& D$ Management 46(2), 369-382.

Gibbons M, Limoges C, Nowotny H, Schwartzman S, Scott P and Trow M (1994) The new production of knowledge. Sage, London.

Haywood J, Connelly L, Henderikx P, Weller M and Williams K (2015) The changing pedagogical landscape: new ways of teaching and learning and their implications for higher education policy. European Commission, Education and Culture, Brussels, Belgium.

Hazelkorn E (2005) University research management: Developing research in new institutions. OECD, Paris.

Helyer R and Lee D (2014) The role of work experience in the future employability of higher education graduates. Higher Education Quarterly 68(3), 348-372.

Holland BA (2001) Toward a definition and characterization of the engaged university. Metropolitan Universities 2(3), 20-29.

Huhtelin M and Nenonen S (2015) A Co-creation Centre for university-industry collaboration-a framework for concept development. Procedia Economics and Finance 21, 137-145.

Ishengoma E and Vaaland TI (2016) Can university-industry linkages stimulate student employability? Education+ Training 58(1), 18-44.

Ivascu L, Cirjaliu B and Draghici A (2016) Business model for the university-industry collaboration in open innovation. Procedia Economics and Finance 39, 674678.

Kelly U, McLellan D and McNicoll I (2010) Making an economic impact: Higher education and the English regions. London Universities, London. 
Ku O, Chen SY, Wu DH, Lao AC and Chan TW (2014). The effects of game-based learning on mathematical confidence and performance: High ability vs. low ability. Journal of Educational Technology \& Society 17(3), 65-78.

Krimsky S (2003) Science in the private interest: Has the lure of profits corrupted the virtue of biomedical research? Rowman and Littlefield, Lanham.

Kulakli A and Mahony S (2014) Knowledge creation and sharing with Web 2.0 tools for teaching and learning roles in so-called University 2.0. Procedia-Social and Behavioral Sciences 150, 648-657.

Kunttu L (2017) Educational involvement in innovative university-industry collaboration. Technology Innovation Management Review 7(12), 14-22.

Macho-Stadler E and Elejalde-García MJ (2013) Case study of a problem-based learning course of physics in a telecommunications engineering degree. European Journal of Engineering Education 38(4), 408-416.

Mascarenhas C, Ferreira JJ and Marques C (2018) University-industry cooperation: A systematic literature review and research agenda. Science and Public Policy. DOI: $10.1093 /$ scipol/scy003.

Masek A and Yamin S (2012) A comparative study of the effect of problem based learning and traditional learning approaches on students' knowledge acquisition. International Journal of Engineering Education 28(5), 1161-1167.

Michael J (2006) Where's the evidence that active learning works? Advances in Physiology Education 30(4), 159-167.

Mirjana PB, Ana A and Marjana MS (2018) Examining determinants of entrepreneurial intentions in Slovenia: applying the theory of planned behaviour and an innovative cognitive style. Economic Research-Ekonomska Istraživanja 31(1), 1453-1471.

Munari F, Rasmussen E, Toschi L and Villani E (2016) Determinants of the university technology transfer policy-mix: A cross-national analysis of gap-funding instruments. Journal of Technology Transfer 41(6), 1377-1405.

Padilla-Meléndez A, Del Aguila-Obra AR and Lockett N (2012) Shifting sands. Regional perspectives on the role of social capital in supporting open innovation through knowledge transfer and exchange with small and medium-sized enterprises, International Small Business Journal 31(3), 296-318.

Perkmann M, Tartari V, McKelvey M, Autio E, Broström A, D’Este P, Fini R, Geuna A, Grimaldi R, Hughes A, Krabel S, Kitson M, Llerena P, Lissoni F, Salter A 
and Sobrero M (2013) Academic engagement and commercialisation. A Review of the Literature on University-Industry Relations. Research Policy 42(2), 423442.

Perkmann M and Walsh K (2007) University-industry relationships and open innovation: Towards a research agenda. International Journal of Management Reviews 9(4), 259-280.

Plewa C, Galán-Muros V and Davey T (2015) Engaging business in curriculum design and delivery: A higher education institution perspective. Higher Education 70(1), 35-53.

Ribeiro-Soriano DE and Berbegal-Mirabent J (2017) Disseminating scientific research: A double-edged sword? Knowledge Management Research \& Practice 15(3), 380-390.

Rusu VD and Roman A (2018) An empirical analysis of factors affecting competitiveness of CEE countries. Economic Research-Ekonomska Istraživanja 31(1), 1-16.

Siegel DJ, Waldman DA, Atwater LE and Link AN (2004) Toward a model of the effective transfer of scientific knowledge from academicians to practitioners: Qualitative evidence from the commercialization of university technologies. Journal of Engineering Technology Management 21(1/2), 115-142.

Somsuk N and Laosirihongthong T (2014) A fuzzy AHP to prioritize enabling factors for strategic management of university business incubators: Resource-based view. Technological Forecasting and Social Change 85, 198-210.

Soendergaard HA, Bergenholtz C and Rosendahl JC (2015) University-industry collaboration: Drivers and barriers for going online. In Proceedings of DRUID Summer Conference, Rome, June 15-17.

Striukova L and Rayna T (2015) University-industry knowledge exchange: An exploratory study of open innovation in UK universities. European Journal of Innovation Management 18(4), 471-492.

Tacer B, Ruzzier M and Nagy T (2018) User-driven innovation: scale development and validation. Economic Research-Ekonomska Istraživanja 31(1), 1472-1487.

Tapscott D and Williams AD (2010) Innovating the 21th century university. EDUCAUSE Review 45(1), 16-29. 
Van de Vrande V, De Jong JP, Vanhaverbeke W and De Rochemont M (2009) Open innovation in SMEs: Trends, motives and management challenges. Technovation 29(6/7), 423-437.

Van Vught F (2009) The EU Innovation Agenda: Challenges for European higher education and research. Higher Education Management and Policy 21(2), 1-22.

Vilalta J, De la Rubia M, Ortís M, Martín ME, Berbegal J and Betts A (2011) Using the economic crisis as an opportunity for engaging universities in regional development. Background report of the First EU-DRIVERS Annual Conference.

Wang Y, Hu R, Li W and Pan X (2016) Does teaching benefit from university-industry collaboration? Investigating the role of academic commercialization and engagement. Scientometrics 106(3), 1037-1055.

Washer P (2007) Revisiting key skills: A practical framework for higher education. Quality in Higher Education 13(1), 57-67.

Wilson KA, Bedwell WL, Lazzara EH, Salas E, Burke CS, Estock JL, Orvis KL and Conkey C (2009) Relationships between game attributes and learning outcomes: Review and research proposals. Simulation \& Gaming 40(2), 217-266.

Wu YC, Lin BW and Chen CJ (2013) How do internal openness and external openness affect innovation capabilities and firm performance? IEEE Transactions on Engineering Management 60(4), 704-716. 
Table 1. Platforms' basic data and main characteristics regarding financial gains

\begin{tabular}{|c|c|c|c|c|c|}
\hline Platform & Founder & Initiative & Foundation date & Traffic rank and visits & Revenues \\
\hline EduSourced & Independent company & Private & 2012 & $\begin{array}{c}4,776,275 \\
(3.2 \mathrm{~K} \text { visits })\end{array}$ & Fees paid by universities \\
\hline CapSource & Independent company & Private & 2016 & $\begin{array}{l}17,574,704 \\
(228 \text { visits })\end{array}$ & Fees paid by universities \\
\hline Demola & Independent company & Private & 2018 & $\begin{array}{c}4,098,488 \\
(4.1 \mathrm{~K} \text { visits })\end{array}$ & Fees paid by universities \\
\hline Nimble Bee & Independent company & Private & 2015 & $\begin{array}{c}5,769,246 \\
(2.6 \mathrm{~K} \text { visits })\end{array}$ & Fees paid by companies \\
\hline Agorize & Independent company & Private & 2010 & $\begin{array}{c}517,591 \\
(62.4 \mathrm{~K} \text { visits })\end{array}$ & Fees paid by companies \\
\hline $\begin{array}{l}\text { Sí Somos } \\
\text { Innovación }\end{array}$ & $\begin{array}{l}\text { University of Oviedo } \\
\text { Foundation }\end{array}$ & Public & 2016 & $\begin{array}{l}20,365,437 \\
(138 \text { visits })\end{array}$ & $\begin{array}{l}\text { Funding from University of Oviedo } \\
\text { Foundation and the City Hall of Gijón }\end{array}$ \\
\hline e-Start & $\begin{array}{l}\text { Fundación Universidad- } \\
\text { Empresa }\end{array}$ & Private (non-profit) & 2011 & $\begin{array}{l}13,706,978 \\
(440 \text { visits })\end{array}$ & Fees paid by universities \\
\hline UC-CROWD & $\begin{array}{l}\text { University Institute of Lisbon } \\
\text { (ISCTE) is the coordinator }\end{array}$ & $\begin{array}{c}\text { Public } \\
\text { (European project) }\end{array}$ & 2013 & NA & $\begin{array}{c}\text { Funding from the Lifelong Learning } \\
\text { Programme of the European } \\
\text { Commission }\end{array}$ \\
\hline Semester of Code & $\begin{array}{l}\text { Initiative of the European } \\
\text { VALS project }\end{array}$ & $\begin{array}{c}\text { Public } \\
\text { (European project) }\end{array}$ & 2014 & NA & $\begin{array}{l}\text { Funding from the VALS European } \\
\text { project }\end{array}$ \\
\hline
\end{tabular}


Table 2. Platforms' main characteristics regarding performance and functionality

\begin{tabular}{|c|c|c|c|c|c|c|}
\hline Platform & Eligibility to join & Matching & Team composition & Scope & Methodology & Ownership of IP \\
\hline EduSourced & $\begin{array}{l}\text { Students from partner } \\
\text { universities }\end{array}$ & $\begin{array}{l}\text { Companies offer } \\
\text { projects to } \\
\text { universities. } \\
\text { Universities accept } \\
\text { them and assign } \\
\text { teams. }\end{array}$ & $\begin{array}{l}\text { Teams are formed of } \\
\text { students with clients } \\
\text { and faculty staff } \\
\text { assigned. }\end{array}$ & Projects & $\begin{array}{c}\text { Project-based } \\
\text { learning; experiential } \\
\text { learning }\end{array}$ & - \\
\hline CapSource & $\begin{array}{c}\text { Students from partner } \\
\text { universities }\end{array}$ & $\begin{array}{l}\text { Universities provide } \\
\text { their learning } \\
\text { preferences, } \\
\text { CapSource matches } \\
\text { with companies in the } \\
\text { network. }\end{array}$ & $\begin{array}{l}\text { Teams are formed of } \\
\text { students with } \\
\text { professionals as } \\
\text { mentors. }\end{array}$ & Projects & $\begin{array}{c}\text { Project-based } \\
\text { learning; experiential } \\
\text { learning }\end{array}$ & - \\
\hline Demola & $\begin{array}{c}\text { Students from partner } \\
\text { universities }\end{array}$ & $\begin{array}{l}\text { Students choose the } \\
\text { project to solve from } \\
\text { those presented by the } \\
\text { partner companies. }\end{array}$ & $\begin{array}{l}\text { Teams are formed of } \\
\text { university students } \\
\text { and industry experts. }\end{array}$ & Projects & $\begin{array}{c}\text { Project-based } \\
\text { learning; experiential } \\
\text { leaning; agile; design } \\
\text { thinking }\end{array}$ & $\begin{array}{l}\text { Students will own the } \\
\text { IP for results of each } \\
\text { project, whereas the } \\
\text { partner company gets } \\
\text { global license to the } \\
\text { co-creation project } \\
\text { results. }\end{array}$ \\
\hline Nimble Bee & - & - & $\begin{array}{c}\text { Teams are formed of } \\
\text { students. }\end{array}$ & Competitions & $\begin{array}{l}\text { Experiential learning; } \\
\text { design thinking; } \\
\text { game-based learning } \\
\text { (competition) }\end{array}$ & - \\
\hline Agorize & $\begin{array}{l}\text { College and young } \\
\text { graduate students } \\
\text { from the Agorize } \\
\text { community }\end{array}$ & - & - & $\begin{array}{l}\text { Projects. Events } \\
\text { (finals) }\end{array}$ & Experiential learning. & - \\
\hline
\end{tabular}




\begin{tabular}{|c|c|c|c|c|c|c|}
\hline $\begin{array}{l}\text { Sí Somos } \\
\text { Innovación }\end{array}$ & $\begin{array}{l}\text { Students from the last } \\
\text { courses of the official } \\
\text { studies taught in } \\
\text { universities, } \\
\text { postgraduate or } \\
\text { master's studies } \\
\text { located in Gijón }\end{array}$ & $\begin{array}{l}\text { Students choose the } \\
\text { project to solve from } \\
\text { those presented by the } \\
\text { collaborating } \\
\text { companies }\end{array}$ & $\begin{array}{l}\text { Teams are formed of } \\
\text { students with } \\
\text { professionals as } \\
\text { mentors. }\end{array}$ & Projects & $\begin{array}{l}\text { Project-based } \\
\text { learning; experiential } \\
\text { learning; canvas. } \\
\text { Agile. Design } \\
\text { thinking }\end{array}$ & - \\
\hline e-Start & $\begin{array}{l}\text { Students from the } \\
\text { partner universities }\end{array}$ & $\begin{array}{l}\text { Universities assign } \\
\text { students to the project } \\
\text { (pre-consulting) }\end{array}$ & - & Internships & - & - \\
\hline UC-CROWD & $\begin{array}{l}\text { Students from the } \\
\text { partner universities }\end{array}$ & - & - & Projects & $\begin{array}{l}\text { Dissertation topics } \\
\text { and open case studies. } \\
\text { Experiential learning }\end{array}$ & - \\
\hline Semester of Code & $\begin{array}{l}\text { Undergraduate } \\
\text { students from partner } \\
\text { institutions, although } \\
\text { in some cases, they } \\
\text { can continue } \\
\text { contributing to } \\
\text { projects once they } \\
\text { graduate }\end{array}$ & $\begin{array}{c}\text { Students accept } \\
\text { mentor project offers }\end{array}$ & $\begin{array}{l}\text { Teams are formed of } \\
\text { students with } \\
\text { professionals as } \\
\text { mentors. }\end{array}$ & Projects & $\begin{array}{c}\text { Project-based } \\
\text { learning. Experiential } \\
\text { learning }\end{array}$ & - \\
\hline
\end{tabular}


Table 3. Main benefits of each type of platform from the stakeholder's perspective

\begin{tabular}{|c|c|c|c|}
\hline Stakeholder & Full experience & Crowdsourcing & Networking \\
\hline Industry & $\begin{array}{l}\text { Save time and money to } \\
\text { obtain solutions. }\end{array}$ & $\begin{array}{l}\text { Attract students to engage } \\
\text { with their problems. } \\
\text { Obtain responses to } \\
\text { challenges from students } \\
\text { from different places around } \\
\text { the world. } \\
\text { Get consumers to also } \\
\text { validate the final ideas. }\end{array}$ & $\begin{array}{l}\text { Increase cooperation } \\
\text { between companies and } \\
\text { universities. }\end{array}$ \\
\hline University & $\begin{array}{l}\text { Adjust course content to } \\
\text { real industry needs. } \\
\text { Include real projects in the } \\
\text { teaching program. }\end{array}$ & $\begin{array}{l}\text { Motivate students with } \\
\text { associated awards. }\end{array}$ & $\begin{array}{l}\text { Bring academics and } \\
\text { companies together. } \\
\text { Collaborate with other } \\
\text { universities. } \\
\text { Access students who } \\
\text { could become young } \\
\text { researchers at the } \\
\text { institution. }\end{array}$ \\
\hline Academics & $\begin{array}{l}\text { Connect with real problems } \\
\text { facing organisations. } \\
\text { Easily track and evaluate } \\
\text { students. }\end{array}$ & $\begin{array}{l}\text { Receive awards and } \\
\text { financial support. }\end{array}$ & $\begin{array}{c}\text { Contact academics from } \\
\text { other countries. }\end{array}$ \\
\hline Students & $\begin{array}{l}\text { Improve the skills required } \\
\text { by industry. }\end{array}$ & $\begin{array}{l}\text { Increase visibility and } \\
\text { contact with companies if } \\
\text { the student's idea is } \\
\text { selected. } \\
\text { Receive awards and } \\
\text { financial support. }\end{array}$ & $\begin{array}{l}\text { Contact students from } \\
\text { other countries. } \\
\text { Receive career } \\
\text { orientation. }\end{array}$ \\
\hline
\end{tabular}

